\title{
Women Role in Environmental Conservation and Development in Nigeria
}

\author{
Raimi Morufu Olalekan ${ }^{1 *}$, Suleiman Romoke Monsurat ${ }^{2}$, Odipe Oluwaseun Emmanuel ${ }^{3}$, Salami John Tolulope ${ }^{3}$, \\ Oshatunberu Modupe ${ }^{4}$, Awogbami Stephen Olalekan ${ }^{4}$ and Makanjuola Bosede Christianah ${ }^{4}$ \\ ${ }^{1,3}$ Department of Community Medicine, Environmental Health Unit, Niger Delta University, Nigeria \\ ${ }^{2}$ Department of Plant and Environmental Biology, Kwara State University, Nigeria \\ ${ }^{3}$ Department of Environmental Health Sciences, Kwara State University, Nigeria \\ ${ }^{4}$ Department of Environmental Health, College of Health Sciences and Technology, Nigeria
}

Submission: June 14, 2019; Published: July 23, 2019

*Corresponding author: Raimi Morufu Olalekan, Department of Community Medicine, Environmental Health Unit, Niger Delta University, Nigeria

\begin{abstract}
Recent studies have shown that one in four women worldwide or about 620 million women rate their lives positively enough to be considered 'thriving' and have shown that women in Nigeria play a crucial role due to their active involvement in conservation activities and management of the environment. However, they are viewed as insignificant partners and not accorded due attention and many women-related economic and social activities depend on environmental resources. Yet, women are denied access to effective and sustainable use of forest resources, and they have limited or no control over land, capital and labour. Women therefore suffer numerous limitations accordingly. As a result of widespread mistreatment and overt discrimination in all dimensions of women lives, women lack significant autonomy. The central preoccupation of this review is to explore the key role of women in environmental conservation and discuss the current challenges and opportunities for the future. Equipped with the right tools, the massive and growing generation of women in Africa, particularly, Nigeria has the potential to drive development, achieve global goals and transform the continent's future along with their own." It is therefore recommended that for sustainable development to take its roots, access and ownership of natural resources should be enhanced for all gender particularly women, people living with disabilities, marginalized and minority groups. Unless women efforts are recognised, we might likely be pushing towards planetary limits and without vibrant women movement, the Sustainable Development Goals are dead in the water thereby, leading to the brink of a global disaster.

Keywords: Gender; Women-related economic and social activities; Environmental resources; Conservation activities; Planetary limits; Global goals; Brink of a global disaster; Sustainable development
\end{abstract}

\section{Introduction}

In the eyes of the general public the conservationist is too often pictured as an antisocial person who is against any kind of development. What the real conservationist is against is unplanned development that breaks ecological as well as human laws. The true aim of conservation, then, is in twofold viz: to ensure the preservation of a quality environment that considers aesthetic and recreational as well as product needs and to ensure a continuous yield of useful plants, animals and materials by establishing a balanced cycle of harvest and renewal.

Thus, a no fishing sign on a pond may not be as good conservation as a management plan which allows for removal of several hundred pounds of fish per acre year after year. On the other hand, if the pond provides the water supply for a town, then some constraints on fishing may be the desirable conservation procedure [1]. Interestingly, recent years have seen an appreciable growth in the level of understanding of the dangers facing the environment and the extensive range of environmental problems is now a subject of serious global concern [2]. These include atmospheric, marine pollution, global warming and ozone depletion, the danger of nuclear and other extra-hazardous substances and threatened wildlife species. Remarkably, only 9.8 percent of Nigeria's total area is under conservation out of which game reserve and national parks form about 3 percent (Figure 1 $\& 2$ ). Most of the areas under conservation have been extensively encroached upon by other land uses and the wildlife resources have suffered serious depletion as a result of over exploitation and gross abuse. More species are becoming endangered daily and the habitats of wildlife continue to dwindle [3].

For indigenous women, the earth is intimately connected with their indigenous culture and it is symbolized as "Mother" because it offers its inhabitants all the resources necessary for their existence and survival. Mother Earth provides forests, rivers and a diverse range of flora and fauna, many of which are useful for medical or 


\section{Ecology \& Conservation Science: Open Access}

technological purposes, contributing to a better quality of life. For this reason, indigenous women feel a tremendous respect for their Mother Earth, and they try to live harmoniously with nature as an intrinsic part of their being. Lies from Western cultures, combined with the imposition of foreign ideas, our concepts and viewpoints about the true significance of the richness of the earth's natural resources went through a process of change. During this process, the belief was formed that these gifts from Mother Earth were limited. Indigenous women were also led to believe that they were an impediment to the development of civilization, and an obstacle to the activities of economic advancement of a country. At the base of this development concept there came the introduction of inappropriate technologies that irresponsibly exploited the land and marine resources, damaging Mother Earth, as well as plundering indigenous people territories. If the indigenous women, have resisted and survived in these tropical jungles until the dawning of the 21st century, this is due to their relationship with and their respect for Mother Earth. Nevertheless, when the conservation of nature and its diverseness is debated, the territorial rights of indigenous women are often forgotten, or if they are recognized they are treated as a ghost, considered a secondary priority. The deterioration of Mother Earth is equivalent to the crisis of global cultural diversity. Indigenous women live in areas of high biodiversity and are confronted as well by many threats against their territorial, cultural and spiritual possessions, and in some areas their very lives are threatened. Women long experience with nature and outside exploitation has been interpreted by and incorporated into our social, economic and political systems, in order to define the territorial limits of our natural resources, and to ensure our existence and future development of new generations of indigenous women [4]

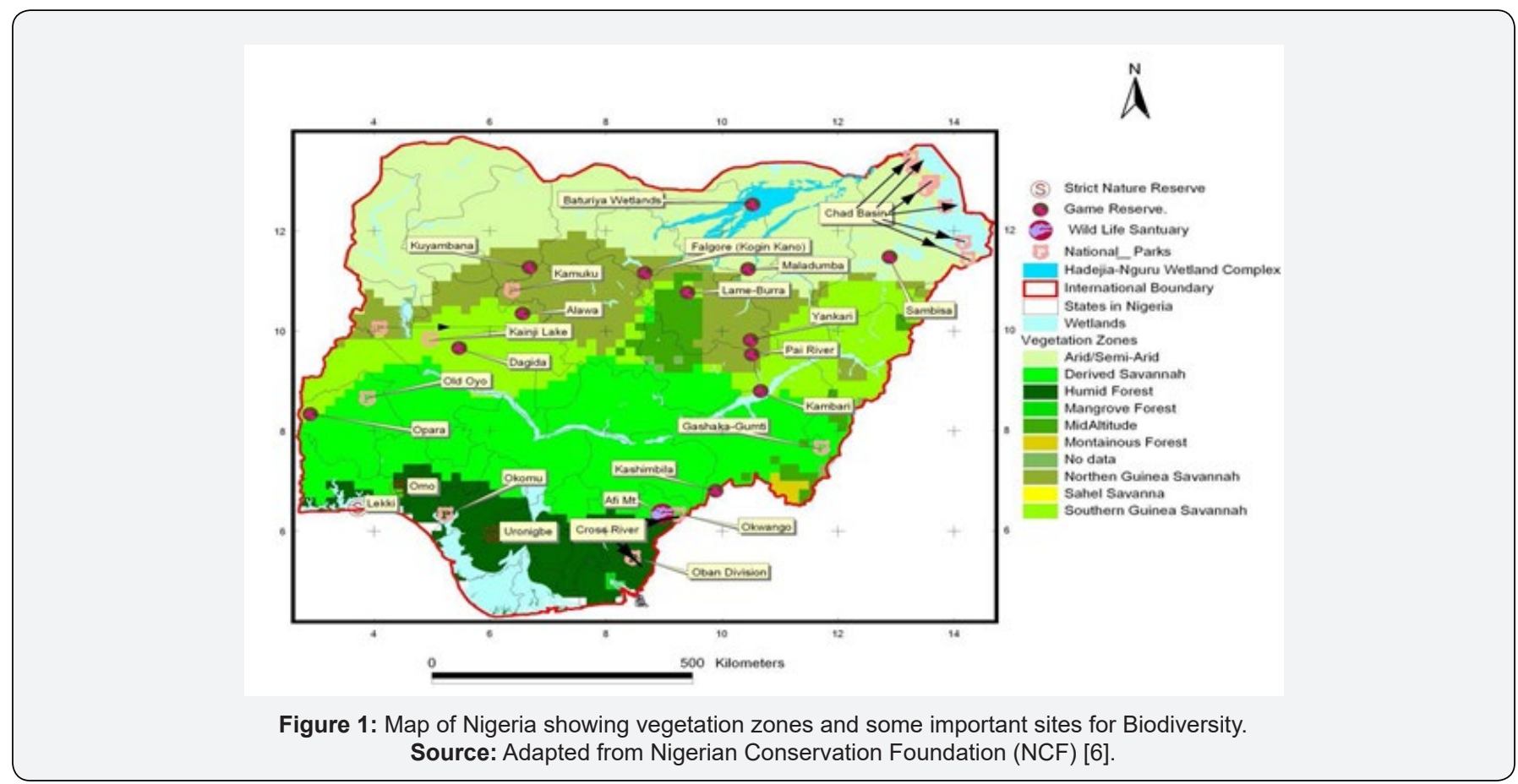

Schematically, appreciating the importance of rural women in conservation activities is essential to rural development planning. In many countries and indeed in Nigeria, the role of women in conservation activities is a helper and not an important economic contributor. Women participating in the development of local and national markets are under-represented in data. Not only do the numbers show us that women are not participating in society at the same rate as men, they are often left out of data considerations in the first place. Even the way that data is collected shows a gender gap. Globally, only 29\% of researchers are women and data allow us to see women (www.unesco.org). That might seem like an odd statement despite we see women daily. They make up about half of our global population and if women aren't counted and aren't accounted for in the data, then policy recommendations will be made without women's consideration (www.unesco.org). Yet, women have use conservation invention for social good and they intensively participate in conservation activities, in addition to their domestic and reproductive functions [5]. Women make up the highest percentage of workforce in the agricultural sector, but do not have opportunity to own or control land and productive resources (Saquina, 2013). However; factors militating against women in their involvement in conservation are numerous, ranging from socio-cultural to economic, as well as changing from area to area. The greatest percentage of rural women all over the world continue to be confronted with poor health and work conditions, limited access to education and low income. In addition, the lack of recognition and appreciation of the significant role of rural women in conservation activities is a drawback that gives rise to lack of specific policies, which are misdirected and thus increase poverty, illiteracy and non-involvement in the design and planning of programs and policies (Saquina, 2013). Women are moving around these obstacles by creating their own 


\section{Ecology \& Conservation Science: Open Access}

spaces and networks to help one another thrive. Women in the Digital Ecosystem (WiDE) is one such community, promoting the inclusion of women in the digital economy ensuring the future is Female.

According to Verveer, (2011) research also indicates that women are more likely to use their earnings or incomes to improve the life standard of their families and communities than men. Beraki, (2009, cited in Abdulahi et al. 2012) asserts that, women frequently endeavour to protect their households, adopting numerous actions, patterns, strategies and mechanisms in the face of shocks and stresses that adversely affects the livelihood of the family. Bryson (1981, cited in Doss, 1999) states that women's role in conservation activities backed by past development but that the failure to accord recognition to enhance their activities is contributing to recent problems particularly, in Sub Saharan Africa. Recognizing that women are prominent in conservation but are accorded little or no opportunity to make necessary contributions to development policies; this study is necessary to elucidate a potential opportunity to improve the lives of rural people by showing the unique circumstances and key position of women as well as their problems and needs that will form a bases of a proper development programme.

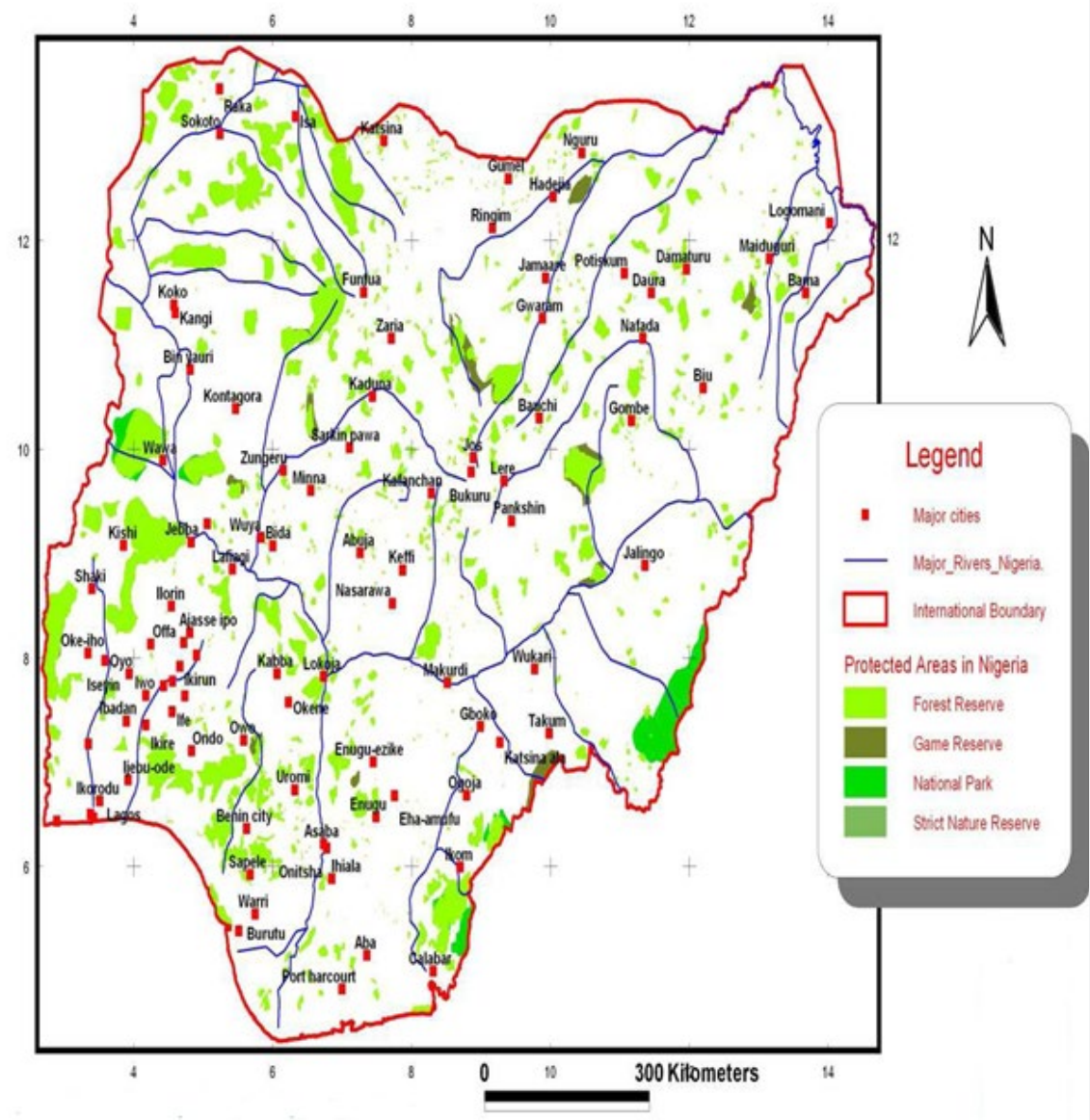

Figure 2: Map of Nigeria showing Protected Areas for Biodiversity. Source: Adapted from Nigerian Conservation Foundation (NCF) [6].

Sustainable Development and Conservation in Nigeria

Man, without basic comforts is an animal; without assurance of his survival, he is a beast. Remove material poverty you will find a fertile soil for refinement. There is a popular sticker that adorns many cars in Nigerian roads. It reads; "Givers never lack" reversing it you get "Lackers never Give". The necessities of life must no longer be taken for granted. The first symptoms of the environmental crisis predicted by some ecologists may be emerging at this moment. These symptoms are reflected in the growing frequency and magnitude of resources shortage.
The quality of life for many of us is now being challenged by real shortages in water, food, forest, minerals and energy. Can man, through science and technology, meet up these challenges and continue to supply these necessities of life? Or will he face everincreasing shortages with a consequent lowering of the quality of life? What is known about the present levels of resources consumption? Can we meet projected future demands for these essential resources?

Nigeria has a total area of approximately $923,775 \mathrm{~km}^{2}$ or 92.4 million hectares and a coastline, which is about $960 \mathrm{~km}$ long. The country is well endowed with vast and varied natural resources, 


\section{Ecology \& Conservation Science: Open Access}

which is a function of its large geographical resources, extent and the diversity of its natural environment. The geographical location of the country and its shape and large size allows it to experience nearly all the different types of weather and climate found in the West Africa sub-region. The vegetation varies regionally in consonance with the climatic pattern. Thus, ecologically, the Nigerian landscape encompasses the mangrove swamps and freshwater swamp forests of the Equatorial region, the moist tropical lowland forest and savanna communities including their montane and sub-montane varieties and scrub lands, characteristic of the semi and Sahel zone.

Table 1: Nigeria Land Use Demarcation. Source: Adapted from [1].

\begin{tabular}{|c|c|}
\hline Types of Land use and Land Cover & Percentage (\%) \\
\hline Grassland & 16.34 \\
\hline Shrub/Woodland/Thicket & 32.01 \\
\hline Forestland & 5.54 \\
\hline Forestland (Mangroves/Swamp/Riparian) & 4.23 \\
\hline Forest Plantation & 0.14 \\
\hline Crop plantation & 0.17 \\
\hline Farmland 60\% intensity & 13.74 \\
\hline Other extensive Farmland Area & 26.68 \\
\hline Water/River Creeks & 0.82 \\
\hline Built up Area & 0.33 \\
\hline
\end{tabular}

From Table 1, it is evident that the distribution of Nigerian land shows that nearly one third of Nigeria is covered by shrub/ woodland/thicket while $48.35 \%$ of the country is covered by grassland, shrub, woodland/thicket. These two land types support Nigeria's grazing economy. Forestland made up of well-drained (dry) land which makes up 5.54\% while forested wetlands cover $4.23 \%$ of Nigeria surface area. All forestland in Nigeria covers $9.91 \%$ or almost $10 \%$ of the area. The whole farmland area covers $40.59 \%$ of Nigeria, showing that only $60 \%$ of the farm is intensively farmland. Tropical rainforests are being destroyed at an alarming rate, notwithstanding their benefits. According to F.A.O estimates the tropical moist evergreen forest is being destroyed at the rate of 11 million hectares a day [1]. Hence, the rate of destruction of tropical rainforests is higher than its rate of regeneration.

Nigeria is underlain by two major groups of rocks namely crystalline igneous, metamorphic and old sedimentary rocks of the pre-cambrian basement complex and sedimentary formations of marine, alluvial and continental origins, dating from the cretaceous to the present. The two rock groups are both characterized by a wide variety of valuable mineral occurrences whose potentials for development are only just being realized. These is a wide variety of lithological rock types which, in turn have given rise to a wide variety of soil types. The Nigerian terrain is quite varied but except perhaps, in a few areas of rugged hills or extreme water logging (Figure $1 \& 2$ ), it does not constitute a major constraint to man's social and economic activities. In fact, the hilly terrains and the poorly drained coastal areas, river flood plains and topographic depressions also have their own unique uses, so that they add to rather than diminish the resources endowment of the country.

Nigeria is well endowed with abundant natural resources, which if properly harnessed and managed can sustain her rapid social and economic development. The need to conserve and plan for the rational development of these resources are more pressing now than ever before because of certain reason:

a) The rapidly increasingly population now estimated about 205 million people (Raimi et al. 2018) and the increasing affluence tendencies among the people especially in the burgeoning urban centres are making great demands on the country's resources.

b) The re-orientation of our economic development strategy which began in the mid-1970s meant placing greater reliance on our own internal resources to promote social and economic development within the country, a situation that has been consolidated more recently with the policy on the local sourcing of industrial raw materials.

c) The emphasis on rural development and small-scale rural producers based on the belief that development is essentially a human issue concerned with mobilizing communities and the whole society to engage in the task of self-improvement with the available local resources.

d) The increasing disharmony between man and nature in several parts of Nigeria as evidenced by the recurrent drought episodes, accelerated gully erosion, oil pollution, proliferation of aquatic weeds, spread of epidemic diseases, crop pest infestations, urban floods, flash floods and dam burst in rural area etc. It was perfectly understandable when the Federal Military Government established the Natural Resources Conservation Council by the Decree 50 (Act 50) of 1989. One of the functions of this council was to formulate a National policy for natural resources conservation which must be based on a full appreciation of the variety of natural resources available; their quantities, occurrences and distribution, their intrinsic characteristics and dynamics; the present state of their development and utilization, the management practices and associated problems.

\section{Gender Issues in Conservation}

The feminist movement in the 1970s and 1980s in the North created an awakening of gender issues in developing countries, although in most cases developments are proceeding very differently than they did in the North. There are few demonstrations or court cases related to women's rights in developing countries. Rather, women in more conservative countries are beginning to examine their role and place in society with more open eyes, and customary gender relationships are being questioned. Northern researchers and development assistance workers are also influencing attitudes and beliefs through the publication of studies and by interventions that put emphasis on women and 


\section{Ecology \& Conservation Science: Open Access}

families. Studies have produced findings that run counter to many preconceived notions about female contributions to household economics and natural resources conservation involvement. In fact, it appears that in most rural communities, women are at least as important than men in contributing labour, products and income to the family. Although women often spend the most time utilizing natural resources, and they are the ones most affected by land degradation, they have little formal say in making decisions about conservation and management questions. Many say this must change if sustainability is to be achieved.

However, western ignorance of the relevance of women in conservation activities and management continue to contribute to the extraordinarily weak performance of rural development interventions among the poor majority in the world. While it is not the only cause of failure, other causes include generally impoverished understanding of the political ecologies of conservation, the paucity of appropriate technical packages, and the often-destructive policies of governments and donor organisations [3], it is certainly among the most salient. A gender sensitive approach to conservation is perhaps even more critical today than it was in 1980 , whether or not conservation in general have continued to deteriorate, it is beyond question that the economic well-being of rural women has worsened markedly and the great brunt of that worsening is being borne by women, children and the elderly. Of these, women's participation in conservation activities have had paradoxical consequences for women regarding their familial relations, gender identity, workload and status. Shifts in household size and structure of authority, network support and marriage patterns, lead to status deterioration for most women [1].

Physical isolation and nuclearization of families have undermined the social bases for women's collaboration, pressed by the need for cash, women are confronted with increasing workloads exactly when the institutional bases for exchanges of service and assistance are being withdrawn and when the ideals of housewifely duties and dexterous performance of feminine domestic chores are gradually gaining prominence as a source of self-esteem among rural women. Remarkably, discrimination against women is related not only to legal measures favouring men but is also rooted in indigenous interpretations of customary rights to land and its products. Women may resist by forming spontaneous collective action groups to counter discrimination and male exclusivity. Under both colonial and national governments, gender discriminatory land-tenue laws increased the intrahousehold struggle between men and women over access to resources. Using familial kinship idioms, men interpreted to their own benefit various state laws that legitimated individuation of land ownership, without commensurately remunerating women's labour [7].

\section{The Women in Development Concept}

Women in Development (WID) concept is centred on theories of modernization and liberal feminism that evolved into a perspective that aimed to integrate women in the development process. The WID-perspective continued to exist within the modernization paradigm, with the focus or intention to develop countries through the adaptation of Western technologies, institution and values [8]. The perspective emphasized on equal opportunities for women, which originated in a liberal perspective on feminism [9]. Liberal feminism, rooted in the tradition of 16th and 17th century liberal philosophy, centred on the ideals and principles of equal rights and liberty. The liberal conception of equality was hinged on the belief that all men had the potential to be rational and that any inequality had to be justified in rational terms. The liberal conception of liberty meant that people were governed only with their consent and only within certain limits, generally defined in terms of the public and private spheres (the former government can regulate; the latter, it cannot). The debate on the dividing line between the two spheres is continuous though with a consensus that the line must be drawn to preserve liberty [9]. According to the first Western feminist theorist, Mary Wollstonecraft (1792, cited in [9]) women's ability to reason was at par with that of men and that male and female biological differences were not important as regards the granting of political rights. She averred that why women appeared to be intellectually inferior was due to their low-level education and, therefore, was due to inequality, rather than a justification for it [9].

Twentieth-century liberal feminists have also used this difference between biological facts and social norms, when they drew the difference between sex (biological) and gender (historical, social, and cultural) differences between women and men. Liberal feminists see women's subordination as resulting from gendered norms, rather than from biological sex, and aim to change these norms. Liberal feminists argue that the inequality of women and men cannot be justified on rational terms and trust that rational men can be convinced of the folly of perpetuating that inequality. Liberal feminists focus on equal opportunities for women and men. Their propagation that women should be treated equally in terms of education and in the application of the law has triggered global campaigns for women's voting and property rights [9]. Policies were suggesting the abrogation of discriminatory actions in institutions or the formation of alternative institutions that are pro women [8].

The liberal feminist approach has been very significant globally and was critical in establishing the language of political strategy utilized by WID advocates [10]. The core thinking of feminism was the idea that women's disadvantages emanated from stereotyped customary expectations held by men and internalized by women and promoted through various agencies of socialization. It postulated that women's disadvantages can, in principle, be eliminated by breaking down these stereotypes: for example, by giving girls better training and more varied role models, by introducing equal opportunity programmes and antidiscrimination legislation, or by freeing labour markets (Connell, 1987) [10]. This approach did not focus on men or gender relations. 


\section{Ecology \& Conservation Science: Open Access}

Modernization theory started in the 1930s, with the early development initiatives of colonial rulers and economists and gained momentum in the post-war and postcolonial periods. Western development planners began to theorize in the $1950 \mathrm{~s}$ about how to promote development in the newly independent countries and came up with projects to modernize less-developed countries all over the globe. Modernization aimed to turn these economies and societies into images of the industrialized, high mass-consumption, democratic societies of the Western world. Obstacles to growth were identified in traditional cultural practices and values, as well as in social and economic infrastructures. Observable, cultural, economic, and political divergence from the model provided by the West was enough to identify a country and its institutions and practices as pre-modern" and in need of immediate change.

\section{The Women in Development Framework}

The framework was advanced or developed with the sole purpose to advance development in developing countries. However, its subordination concerns remained central to the women's movement in many northern countries. WID had the primary motive to improving the status of women by given attention to their roles and integrating them into the economy. The essence is also to enhance the productive roles and capacity of women. The origin of women's subordination was linked to their exclusion from the marketplace. It was therefore argued that if women were given the opportunity to be actively involved in productive sphere, they will no doubt, contribute meaningfully to development. By implication, they will make positive development contribution and advance their status in relation to the status of men [10]. WID refused to accept the restrictive and narrow view of women's roles (as mothers and wives) surrounding most of development policy in relation to women. Rather than referring to women as mere needy beneficiaries, WID assertions push forward arguments that properly portray women as inspiring and productive in societal scheme of things. No longer, therefore, should women be considered as inactive recipients of welfareoriented programmes but rather as active participants and contributors to the enhancement of society economically. This Implies that women contribute to the economic development of countries. Women can therefore be regarded as a missing link in developmental actions and activities, a hitherto less valued economic resource in the development chain (Tinker, 1990) [10]. The WID approach had gone through changes all through the 1970s and the 1980s. There had been a shift in focus from the aspect of Equity to Anti-poverty, and, then to Efficiency approaches in the pursuit of women development.

\section{The Equity Approach}

The equity approach emanated from the United States of America. It is considered as the original WID approach. The WID approach became pronounced after its introduction by the WID movement. Its popularity became widespread during the United Nations Decade for Women. Its basic assumption is that women are impacted negatively by economic growth. The approach thus calls for or solicits for equitable distribution of the proceeds of development. That is ensuring that both men and women share such developmental benefits equally. The approach also pushes for proper integration of women in the developmental scheme of things by means of having marketplace and employment opportunities. It is pertinent to note that the equity approach extends beyond economic inequality as it addresses women subordination even at the level of households and at the open market. The approach also focuses on ensuring equity between men and women by addressing the issue of inequality between the sexes in private and public domains respectively and along the line of socio-economic groupings [11].

In order to solve the problem of inequalities between the sexes, women and men, the equity approach requests for the intervention of the state in ensuring that autonomy was obtained for women. They sought for top-down kind of intervention that will be inclusive of both political and economic autonomy. They referred to the approach as top-down. [11] explains the resistance launched against the equity approach regarding its ability to solve the problem of resource redistribution in terms of taking from men to give to women for equity and also to swing the pendulum of power so that men and women will hold power equally to prevent the subordination of women. The approach tackles the existing inequality that keeps men and women on separate platforms. The approach identifies a strategic need for women to be treated equally both economically and politically and, to be seen from the perspective of both reproductive and productive roles. A major shortfall of this approach is that it stands as a threat to the dominion of men and thus looks difficult to implement. It thus was diluted to make it more appealing to accept and implement [11].

\section{The Anti-Poverty Approach}

The anti-poverty approach is a much milder WID approach compared to the equity approach because the emphasis is on income equality reduction between men and women rather than reducing inequality between men and women. The anti-poverty approach became pronounced in the early 1970 (Moser, 1993). Its emphasis is on women that have low income with the intent of reducing poverty. According to Buvinic (1983) [10], the emphasis on low income women who are considered made the approach appealing to bureaucrats and those who are responsible for the implementation of policies. This is because of the less threatening tone of the advocacy. The implication of this is the emergence of two conflicting anti-poverty strategies since the direct poverty reduction was based on maximizing GNP [10].

Strategy one was to increase the income of people by the provision of employment and, by increasing the income of poor and insolvent workers. Strategy two known as basic needs' strategy entails that the whole essence of development was to meet or fulfill the basic human needs which are basically food, clothing and shelter including social needs such as human right, education and political participation and involvement. [10]. In 
the 1970s, there was widespread adaptation of the anti-poverty approach by various internationally established agencies and countries. Examples of such are World Bank and International Labour Organisation (ILO) [10]. The implementation of the antipoverty approach was basically to fulfil the aspiration to surge women's employment. That informed why the concentration was on programmes that were meant to increase the employment of women and to cause revenue generation (i.e. skill training) as well as creating accessibility to productive resources (i.e. credit) (Buvinic, 1986) [11].

\section{The Efficiency Approach}

This approach came to light during the 1980s. The approach is still widely relevant till date. Its emergence came at a period the world was embracing neo-classical economic model. The nexus of the model is centered on the point that the world has an amount of resources and that the said resources with the use of economics tool be rationally allocated. This implies that existing resources which are scarce are allocated in such a manner that will be of interest to the economy. People exhibit rational behaviour whiles this model is applied. It follows the use of cost benefit calculus to maximize personal interests. One prominent feature of this approach is the compulsive best interest attitude that people exhibit resulting in the most efficient utilization of available resources in the economy. Supply and demand hold sway because it determines the allocation of resources which takes place through markets. Markets are very fundamental in this regard because it guarantees an economy that is self-equilibrating. It causes economies to have sustainable growth that is of long run. Based on the positive traits of the free market, it is averred that government should only intervene in the advent of an imperfect market (Sparr, 1994) [11].

This approach which emanated from the neo-classical economic model considers women as assets that are underused or abandoned in relation to development. Thus, the essence of this approach is to cause the efficiency and effectiveness of development through the contribution of women. The core assumption is that higher economic participation amounts to increased equity. The efficiency approach emphasizes economic growth and sees women as input factor in relation to the economy.

\section{Theory of Public Participation}

Public participation is a process that accords individuals the opportunity to influence public decisions in given societies. These individuals are particularly private individuals that influence public decisions. It was created in the mid-1960s. President Lyndon Johnson's Great Society Programmes was the originator (Cogan \& Sharpe, 1986) [12]. The participation theory has its root from political sciences and development theory. The fact that the poor people in the society are often not taken into consideration on developmental issues triggered the creation of the participation approach. It came to be since the poor are often alienated from decision making processes, including implementation and attendant benefits. This background root of the approach makes it important as it advocates for the inclusion of the poor in developmental processes just as the others in the society are equally being planned [13]. Public participation is now a part of development process from the 2000s. The problem is how well the process is handled being certain of its benefit to decision making, the generality of the public as well as the practice of inclusion in development [14]. The words Public and Citizen Involvement and Participation are often used alternatively. They have a common reference to a process which allows private individuals to influence public policy decision. Their explanation of the process is basically vague though with meanings (Mize, 1972) [12]. The word citizen excludes those with no formal or proper citizenship status. Imperatively, public participation requires legitimacy and quality. This, however, depends on the process designed. Legitimacy of the process is based on how adequate participation and objectivity of the process is handled. Also noteworthy is the policy efficiency [14]. Examples of participation are town hall meetings, or public hearings etc. The aim is to ensure that policies are made in manners that will be of utmost benefit to the generality of the public considering the divergence and uniqueness of the populace for whom the policies are made. Policies should be well planned. The best possible outcomes should be considered and implemented to enhance developmental goals.

\section{Environmental Movements lead by Women around the World}

\section{Green Belt movement}

This movement is one of the biggest in women and environment history. Nobel Prize winner Wangari Maathai founded this movement on the World Environment Day in June 1977 , involving 80,000 women in planting of trees. The Green Belt movement aims to bring environmental restoration along with society's economic growth. This movement led by Maathai focused on restoration of Kenya's rapidly diminishing forests as well as empowering the rural women through environmental preservation.

\section{Kenyan land takeover}

In Kenya, starting in the mid-1980s, women protested the elites and big foreign corporations who were coerced and controlling the production of the land. Rather than allowing food to be grown for survival, women were pressured by both their husbands and the government to cultivate coffee for foreign profit. The protests continued and gained strength over the next couple of decades. The protests eventually ended in a Kenyan power shift enforcing democratic national elections, which resulted in the redistribution of land.

\section{Women Concern for Nature around the World}

Women around the world play a key role in the protection of biological diversity. They have recognized the need not only to protect the biodiversity, but also to reshape and recreate it. 


\section{Rachel Carson}

One of the outstanding women environmentalists is Rachel Carson. Rachel Carson (1907-1964) was a scientist, writer, and ecologist. Rachel Carson wrote the now-famous Silent Spring, an expose on the misinformation spread by the chemical industry and the use of synthetic pesticides, specifically DDT. This book spurred the environmental revolution. The overall theme of the book is the commanding- and overwhelmingly negative effect that humans have on the natural world. Carson's legacy led to the creation of the Environmental Protection Agency in the United States under the Nixon administration and started the conversation regarding the human impact on the environment.

\section{Wangari Maathai}

Wangari Maathai worked tirelessly for both land conservation and women's rights. She was the founder of the Green Belt movement, which focused on environmental conservation and women's rights, in her native country of Kenya. In addition to being honoured by many world leaders for her efforts, she was awarded the Nobel Peace Prize in 2004 for her approach to sustainable development, democracy and peace.

\section{Isatou Ceesay}

Isatou Ceesay, dubbed "Queen of Recycling," is a Gambian activist who started the recycling movement called One Plastic Bag in the Gambia. Ceesay works to educate citizens about recycling and reducing the amount of waste that is created. She founded a project that creates plastic yarn and forms bags out of the upcycled waste. Not only has her project dramatically reduced the amount of waste in her village, but it is also employing hundreds of West African women and providing them with monthly revenue.

\section{May Boeve}

May Boeve is co-founder of the website, 350.org, an organization dedicated to working against climate change by connecting leaders across the world. The aim of the organization is to reduce the levels of carbon dioxide in the atmosphere to a point where global warming will not be as dangerous as predicted. Her organization is going straight to the source: the fossil fuel industry. By limiting the power of the industry, itself, they hope to then confront the government about limiting carbon dioxide emissions.

\section{Marina Silva}

Marina Silva is a warrior for the Amazon Rainforest in Brazil. Silva was a colleague of Chico Mendes, who was assassinated for defending the rainforest in 1988. She and Mendes led demonstrations in the 1980s to protect the rainforest from government control. After Mendes' assassination, Silva became a politician and fought for environmental protection, sustainable development, and social justice. Deforestation decreased by $59 \%$ from 2004 to 2007, during her political career.

\section{India Women Role in Conservation of Environment}

Environmentalists are those who work towards the betterment of our environment, these are the people who have lobbied for environmental protection when the common man would rather sleep peacefully and care for his own benefit. These people have worked for a cause greater than them. By saving the environment for global commons and have saved and impacted us too. The origin of the environment protection movement dates back to Kehjrali movement and gain momentum through Chipko movement, Appiko movement, Save Silent Valley movement and Narmada Bachao Andolan and the major trend in the environmental protection, emphasising the fact that environmental movements reflects the trend that most participants are women, Adivasi's, and poor people $[15,16]$. Women and environment are closely bounded and the intimate relation between women and nature led to the emergence of theory of ecofeminism, which is a field bridging ecological ethics and feminism that seeks to explore the conceptual connections between environmental degradation and sexist oppression [17]. Women through their role as farmers and collectors of water and fire-woods have a close connection with their local environment, women and children as well as marginalised sections are the prime victims of environmental degradation especially at times of natural disasters $[18,19]$. Thus, women actively participate in environmental protection than men as women are directly affected and influenced by nature than men [20]. Women have been involved in several governmental \& nongovernmental forestry \& environment programs.

a) Chipko movement

b) Community forestry programs

c) Social forestry programs

d) Individual conservation programs

e) SHGs conservation programs

f) Green-Belt movement

g) Keep the city clean programs

h) Green India clean India programs

The sustainable use of the environment by women is the result of their closeness to nature. Most women, especially in rural areas, are involved in household activities like the collection of food, water, fodder and fuel, which enhance their knowledge of the environment, thus enabling them to implement the appropriate conservation practices and technologies. (Ram Pandit \& Eddie Bevilacqua, 2011) Social Heterogeneity and Community Forestry Process). People in Western countries think they originated the environmental movements without knowing that the villagers in mostly poor and developing countries initiated these movements.

\section{Environmental Movements lead by Indian Women}

\section{Bishnoi's first environmentalists of India}

The direct concern of Indian women with environmental protection can be traced long back to 1731 A D, The Bishnoi people of Rajasthan credited for the first use of Chipko tactics against tree felling [21]. Bishnois movement began with the 
royal order of Maharaja Abhay Singh to cutting of Khejri trees, worshipped by Bishnois, for construction of fortress. The villagers under the leadership of Amrita Devi protested the order as she hugged the tree, as a new form of dissent. Amrita Devi and her three daughters were beheaded for disobeying royal order. Just before her martyrdom, Amrita Devi declared, "If a tree is saved even at the cost of one's head, it's worth" [22]. Maharaja stopped order as 363 Bishnois lost their lives in non-violent method for protection of trees. They are upholding eco-friendly principles still by saving water by traditional water harvesting system, indigenous cultivation method for local areas and not killing any animals [23]. Thus, Bishnois movement laid the foundation of environment protection movement in India. This movement started by Amrita Bai in 1731 A D was revived by Bachni Devi and Gaura Devi of Uttar Pradesh in 1972. They snatched the axe from the wood cutters and warned contractors not to cut the trees.

\section{Chipko movement (1973)}

Chipko movement was started in 1973 at Garhwal division of Uttar Pradesh specially Chamoli District. The protest movement was organised by Chandi Prasad Bhatt, who aired the slogan of "ecology is permanent economy". Chipko movement was led by Sunderlal Bahuguna, Bachi Devi, Gauri Devi and women of the Garhwali area saved trees by embracing them. Again in 1977 many rural women saved the Adwani Forest under the leadership of Bachchni Devi. The movement begin with the government refusal to supply ash tree to the Dasholi Gram Swarajya Mandal (DGSM), (workers' cooperative) for processing plant of forest produces (especially for making plough) in Chamoli District. Instead government gave green signal for Simon Company to cut ash trees for production of sporting goods. The DGSM organised protest government decision to promote Simon Company instead of villagers. This boosted the Chipko protest. Women formed Mahila Mandal for the protection of forest as they understand the forest degradation has more direct impact on their lives. For poor men of the area development opportunities by the Simon Company are new avenues for reducing the dependence on women, by woks on hotel, and construction works. But women want to preserve the status quo and protect environment through forest protection of Garhwali Hills as it is the question of their survival [24]. The method of tree hugging protest led by Gauri Devi and Bachi Devi found success against chopping down the trees. Simon Company stopped cutting of trees. The main slogan of women was, the forest is our mother's home, we will defend it with all our might which prove their eagerness to protect forest [23].

\section{Appiko movement (1983)}

Appiko movement is important environmental conservation movement in Karnataka, to protect Western Ghats forest. Appikko movement was initiated by Panduranga Hegde. In September 1983, men, women and children of Salkani (a village in Western Ghats) "hugged the trees" in Kalase forest [25,26]. This movement was against government policy to open forest for industrial development. The members of Mahila Mandal include Adivasi women joined for protection of rainforest by writing down to the government for halting of woodcutting. The village women conducted awareness programmes through foot marches, slideshows, folk dance, street plays, and dramas (Karan, 1994). Thus, with the strong protest from people, Government forced to halt industrial policy on Western Ghats which resulted in destruction of forest $[27,28]$.

\section{Silent Valley movement (1976)}

Silent Valley is one of the important biodiversity hotspots in Southern end of Western Ghats in Kerala. The Silent Valley Movement was against the decision of Kerala Government to construct a dam for hydroelectric power project in the Silent Valley forest [29-31]. The Malayalam poet and environmentalist, Sugatha Kumari was the prominent leader in this movement. Despite the offer of employment and development in the area, people, especially women opposed the hydroelectricity project. As a result, the project was cancelled by personal interventions of the then Prime Minister Indira Gandhi in 1980 and Silent Valley was declared as a National Park in 1984 [32].

\section{Narmada Bachao Andolan (1985)}

India's Narmada Bachao Andolan (NBA) is an environment movement against the building of several dams along the Narmada River funded by World Bank. The NBA spread to three states of Gujarat, Maharashtra, and Madhya Pradesh as the construction of Sardar Sarovar Dam affect the environment and settlement of people of these areas. NBA, which led by the Medha Patkar, Baba Amte, and Arundhati Roy had turned into the International protest, gaining support from NGO'S all around the globe. With strong protest from NBA World Bank withdraw project in 1993 $[33,34]$. But the case continued in Supreme Court.

\section{Navdanya movement (1984)}

Navdanya is India's largest organic movement. Navdanya began in 1984 as a program of the Research Foundation for Science, Technology and Ecology (RFSTE), a participatory research initiative to provide direction and support to environmental activism. "Navdanya" means "nine crops" that represent India's collective source of food security (Preston-Pile, 2007). The main aim of Navdanya is to save seeds from biopiracy and with this intention, setup 111 Community seed banks in 17 states in India [35]. They are strongly campaigning against Genetically Modified Seeds and actively participating in biodiversity conservation [36]. Mostly the members of Navdanya Movement are women farmers from various parts of country.

\section{Women Concern for Nature Around Nigeria}

Women have an integral relation with the environment. Therefore, women are essential for any measure aimed at environmental conservation, protection and sustainable development. In fact, women have contributed greatly to the conservation movements in the past. 


\section{Ecology \& Conservation Science: Open Access}

Women through their roles as farmers, collectors of water and firewood, have a close connection with their natural environment and often suffer most directly from environmental problems. Most studies on women and environment have revealed that women are significant actors in natural resource management, and they are major contributors to environmental rehabilitation and conservation $[37,38]$. Throughout history, women have been immortalized as powerful symbols of nature: Mother Earth, Earth Goddess, and Artemis in the Greek mythology, and Mother River (the Yellow River) in Chinese history. In addressing most of the current environmental issues such as climate change, ozone depletion, environmental pollution and environmental degradation it has been reported that women play a major role [38]. Women because of their direct interaction with environment have made them have deep knowledge about the environment [39]. Thus, making women serve as agriculturalists, water resources managers and traditional scientists among others. According to Shettima [40] reveal that Women are not only knowledgeable about the environment, they are also protective and caring towards environment.

Among Nigerian FulBe, Women were responsible for the direct marketing of milk and milk products, while men were responsible for the indirect marketing of livestock, using a professional broker. Although women's individual transactions are smaller than are men's, they aggregate sales by women contribute substantially to household income and therefore to women's status. Thus, even its total household income was to increase through an emphasis on beef rather than on dairy production, an often assumed through rarely demonstrated proposition, the relative contribution to that income from women would decline. Women's labour contribution to stratified production schemes is interpreted as part of their feminine role and therefore, remains devalued and of low visibility, overshadowed by the dominance of men in these enterprises. While women may contribute heavily in the labourintensive task of caring for the calves, their male relatives control income from sales to ranches and feedlot operators. Excluded from the male run animal marketing network, women even lose control over their own livestock as men will first sell off animals that belong to their wives.

All over the world, women contributed to agricultural production. They produce more than half of all the food that is grown (FAO, 1996). In sub-Sahara African and the Caribbean, women produce $80 \%$ of basic food stuffs, in Asia they provide fifty to ninety percent of the labor force for rice cultivation. In Nigeria, 60\% are involved in farming in Adamawa State Nigeria [41]. Also, women in Imo state, Gurei district of Adamawa state and many Igbo part of the country has been reported to contribute to food production and even undertake some of the conventional male agricultural tasks (Adebayo 1998; Ezumah and Domenico, 1995). As victims of soil degradation, women have participated actively in soil conservation projects i.e. the project Agroforestia in Yatenga, Burkina Faso. It was also found that women in Liberia and Sierra Leon, through their daily activities such as cooking and cleaning, add organic matter such as ash, potash and left-over food and stalk onto the soil to form African Dark Earth [42]. The aim is to enrich soil which is solely based on traditional knowledge and is said to improve soil quality. In addition, [43] studies in Kaduna State show that women are actively involved in environmental protection by engaging in sprinkling water on the soil before sweeping. This, the women say protects topsoil, which in turn helps cub surface erosion.

Studies also shows that in Nigeria, where semi-sedentary Fulani women have overseen milk processing and distribution, dairy development efforts have concentrated on high-technology operations that process non-indigenous dairy products for urban consumers. Hindered by low milk output and discouraged by low prices offered by large dairy plants, Fulani women rarely are willing to sell their milk to non-local markets. Absence of infrastructure and preservation technology has so far prevented most women's direct access to urban consumers. In rural markets fermentation techniques adopted by women solve the danger of contamination and combat the problem of lactose intolerance common in sub-humid areas [44].

Similarly, the rate at which biological diversity (especially the forest ecosystem) is been loss, there is raise in the need to protect it. This is because forests play a vital role in protecting the soils, water sheds, climatic stability and serve as source of many products (charcoal, firewood, pharmaceuticals, latex etc.). The main sources of energy (cooking fuel) for women are from natural resources such as charcoal, firewood and kerosene, intensive use of these energy sources can lead to deforestation, soil degradation and air pollution. Only very few rich women use gas or electric cookers. The interesting part of the whole dilemma is that we have greater women participation in forest management through tree planting, rehabilitation or protection. The green Belt movement of Kenya where over 7 million trees were planted in 10 years and set up over 1000 tree nurseries to the extent that it harvested fuel wood from its own trees and the fruit trees are bearing fruits. In Nigeria the situation is the same, Adebayo et al. (2001) reported that $70 \%$ of women in Adamawa state, Nigeria have planted trees in the last five years in their compounds and $21 \%$ planted trees on their farms. [38] studies in Plateau State, Nigeria also shows that the commonest method employed by the women in soil conservation is mulching. In addition, Oloko [43] studies in Kaduna state Nigeria revealed that thirteen percent $13 \%$ ) of women said they engage in sustainable harvesting so that those plants would be available for next time. However, they admitted being cutting tree branches in ways that would allow for future germination of such tree. The Society for Women and Vulnerable Groups (SWOVUGE) is also helping communities to restore and sustainably manage mangrove forests in the five villages of the Ukpom Okom District in South East Nigeria [45]. This is to show that women are actively participating in protection of biodiversity either through planting tree or raising seedling in nursery and 


\section{Ecology \& Conservation Science: Open Access}

flowers to beauty the environment or harvesting resources in a sustainable way.

Moreover, in many cases, enhancement of urban ecosystems provides multiple co-benefits for health such as clean air and temperature regulation [5]. Ecosystem-based Adaptation (EbA) can further create synergies between adaptation and climate change mitigating measures by assisting in carbon sequestration and storage and enhancing various ecosystem services considered beneficial for human health $[46,47]$. Trees has been known to play such roles as surface cover for our land, erosion mitigants, carbon sequesters, temperature regulators, they are catchment area for underground water, they serve as water shed in the upland, improve transpiration and provide shade, they are important piece in keeping a balance in our ecological systems, provide refuge for many endangered species of mammals, birds and reptiles, preserve the environment by filtering pollutants from the water, create a barrier that protects coastal areas from storms and tides, they are known as salt excluders, have filters that prevent the entry of salt through the root surface, they are also known as salt secreters, letting the salt into the plant but then quickly secreting it, usually through special salt glands on the leaves, their latex has medicinal properties and has been used to treat sores and stings, they form the basis of a complex food web, leaf litter and disintegrating vegetation are a source of food for microorganisms, many living things makes the tree their home, their feeding ground, their breeding habitat, or their nursery, trees are very useful ecosystem/regulators of micro climate and prevent surgent wind, they serve as nostril for birds and ecosystems, there is a lot of mineral resources been deposited, they are a big lungs of the ecosystems, they are particularly considered to be efficient in reducing concentrations of pollutants, although the capacity can vary by up to 15 times between species $[3,48,49]$. Green urban design can reduce obesity and improve mental health through increased physical activity and social connectivity [50]. Increased neighbourhood green spaces reduce both morbidity and mortality from many cardiovascular and respiratory diseases and stressrelated illnesses [51]. Tree canopies have a higher albedo effect than other hard surfaces and can work to reduce the urban heat island effect, lowering heat mortality by $40-99 \%$ [52]. Whilst resulting in improved public health and community resilience, many of these measures will also act to mitigate climate change.

In term of waste disposal and management, women are actively involved because they are closer to the environment. They engage in environmental management by cleaning the environment and keeping it clean especially in terms of garbage disposal. Giving the health hazard of garbage, women see to its regular disposal at the community level by doing it themselves [38]. According to Kwagala [53] in his study in Kampala, Uganda observed that Drains are mainly cleaned by the women on a regular basis or pay to have them clean. In the south western part of the country, women in Pedro Village, Lagos state were found to be protective and conscious of their environment. They manifest this by engaging in waste management, drainage management, water resource management, flood management and subsistence agriculture; these are all efforts towards protecting their environment [54]. As a coastal community, they often experience flooding and that could be further exacerbated by blocked drainages and improper waste disposal. The study by Chukwu [54] shows that women play an active role in protecting their community and serve as enforcers of guidelines and penalties.

\section{Some Global Conservation Organizations}

Table 2: Some Institutions involved in ex-situ and to a little extent, in-situ conservation efforts in Nigeria. Source: Adapted from [1].

\begin{tabular}{|c|c|c|}
\hline Institutions & Community & Conservation Method \\
\hline Cercopan, Calaber & $\begin{array}{l}\text { Monkeys: Guenons (Cercopithecus) and Mangabeys } \\
\text { (Cercocebus) }\end{array}$ & $\begin{array}{l}\text { Sanctuary and rehabilitation of orphaned } \\
\text { Guenons, captive-breeding, eventual release } \\
\text { into the wild and monitoring. }\end{array}$ \\
\hline $\begin{array}{l}\text { Drill Rehabilitation and Breeding } \\
\text { Centre (Pandrillus) Calaber }\end{array}$ & Drill (Mandrillus leucophaeus) & $\begin{array}{l}\text { Rescuing and breeding animals in captivity, } \\
\text { rehabilitation into social groups and release } \\
\text { programmes }\end{array}$ \\
\hline $\begin{array}{l}\text { Forest Research Institute of } \\
\text { Nigeria (FRIN) }\end{array}$ & Forest trees and fruit trees & $\begin{array}{l}\text { In-situ, ex-situ seed gene-bank and live field } \\
\text { gene-bank (Arboretum) }\end{array}$ \\
\hline $\begin{array}{l}\text { Rubber Research Institute of } \\
\text { Nigeria (RRIN) }\end{array}$ & $\begin{array}{l}\text { Latex producing plants (Hevea brasiliensis, Funtumia elastica } \\
\text { and Acacia sp.) }\end{array}$ & $\begin{array}{l}\text { Mainly ex-situ seed gene-bank and live field } \\
\text { gene-bank }\end{array}$ \\
\hline $\begin{array}{l}\text { Cocoa Research Institute of } \\
\text { Nigeria (CRIN) }\end{array}$ & $\begin{array}{c}\text { Cocoa (Theobroma sp) Coffee (Coffee spp.) Tea (Camelia } \\
\text { sinensis), Cashew (Anacardium occidentalis) Cola (Cola Spp.) }\end{array}$ & As above plus in vitro \\
\hline $\begin{array}{l}\text { Nigerian Institute for oil-Palm } \\
\text { Research (NIFOR) }\end{array}$ & $\begin{array}{l}\text { Oil palm (Elaeis guineensis). Raphia (Raphia hookeri), Coconut } \\
\text { (Cocos nucifera) }\end{array}$ & $\begin{array}{l}\text { Mainly ex-situ seed gene-bank and live field } \\
\text { gene-bank }\end{array}$ \\
\hline $\begin{array}{l}\text { International Institute of tropical } \\
\text { Agriculture (IITA) }\end{array}$ & $\begin{array}{c}\text { Cowpea (Vigna unguiculata) Yam (Dioscorea sp.), Banana } \\
\text { (Musa sp) Maize (Zea mays), Rice (Oryza sativa), Taro } \\
\text { (Colocasis esculenta) }\end{array}$ & As Above \\
\hline $\begin{array}{l}\text { National Horticultural Research } \\
\text { Institute, (NIHORT) iBADAN }\end{array}$ & $\begin{array}{l}\text { Vegetables and fruits Tomato (Lycopersicum esculentum) } \\
\text { Pepper (Capsicum spp.) Onion (Allium cepa) Melon } \\
\text { (Colocynthys citrullus), Okra (Abelmoschus esculentus), Bitter } \\
\text { leaf (Vernonia spp) Fluted pumpkin (Telfairia occidentalis) }\end{array}$ & As Above \\
\hline
\end{tabular}


Some international organisations that have done a lot in bringing awareness to the status of our resources and need for their conservation include IUCN; WWF; UNEP; Friends of the Earth and Green Peace. In Nigeria, we have the then FEPA and its state counterparts such as the Akwa Ibom State Environmental Protection Agency (AKSEPA). These have now been subsumed under the respective Ministries of Environment. We also have developmental partners i.e. non-governmental organization (NGOs) [3] such as the Nigerian Conservation Foundation (NCF), The Nigerian Society for Biological Conservation (NSBC) and the Nigeria Environmental Study/Action Team (NEST). Most environmental organisations are voluntary and act as pressure groups in influencing government policies that are likely to affect the environment. They also aid in setting up and managing nature preserves. In many European countries, environmentalists are no more satisfied with merely acting as pressure groups on Government. They are now proactive and are forming political parties known as Green parties, with environmental issues given high priority in their manifestoes. They have made significant gains in elections in Germany, Sweden etc and are becoming a formidable force to reckon with many other European Union (EU) countries. They organise consumer boycotts, picketing and blacklisting of companies whose activities are not considered environmentally friendly. Similarly, some institutions involved with ex-situ conservation in Nigeria are shown in Table 2.

Traditional Ways of Conserving and Protecting the Nigerian Environment

\section{Re-orientation}

Nigerians need a completely new orientation or another ethical revolution to change our attitude towards the environment.

\section{Mass literacy campaign}

For adequate and effective orientation of Nigerians especially at the rural level, mass literacy campaign is necessary to educate more than $80 \%$ of the people who are illiterates and therefore cannot understand as well as appreciate the essence of environmental conservation and protection.

\section{Mass enlightenment campaign}

There should be mass enlightenment campaigns in the villages against environmental abuse such as uncontrolled bush burning, use of fertilizers, overgrazing, deforestation $(90 \%$ permanent loss in natural habitat of pollinators critical to agricultural production and $\$ 1$ billion annual loss in non-timber forest products due to rapid deforestation), etc. this should be carried out through such media as the village criers, the landlords, management committees, community development associations, church, schools etc. to convey the message to all nooks and corners of the villages/communities.

\section{Review of the land use system}

Whereas land can be kept to fallow, the concept of bush burning should be discouraged because it destroys the leaves, sticks, grasses etc. which would have enriched the soil. Compost manure, which is derived from decaying leaves, sticks, grasses etc is natural, more productive and less harmful to the soil, crop, human and animals. It sustains the environment much better and longer too.

\section{Forest tracing}

To avoid indiscriminate bush burning, communities should embark on forest tracing at the beginning of every year by clearing forest paths of dry leaves, sticks etc. So that fire in one area will not extend to another area.

\section{Control of forest exploitation}

Foresters, Conservation Clubs, local chiefs and individuals should work together to save our forests from undue exploitation. Government should ensure that forest laws are enforced to protect the forests.

\section{Abolition of some Habits}

Habits such as Argungu festival in Sokoto and annual fish harvest in Boki etc where even the fish eggs are harvested as well as hunting and poaching with extinction should be discouraged and stopped.

\section{Re-afforestation}

This is the planting of trees plants to replace the ones destroyed through lumbering, bush clearing and burning and excessive fuel wood harvest. Trees are catchment areas for underground water and water sheds in the uplands. They help to regulate the climate, provide habitat for wild variety of plants animals found nowhere else, bind the soil to the ground, act as wind breaks etc. in other words trees sustain the environment.

\section{Formation of conversation clubs}

Conservation clubs should be formed in our schools and villages as a channel of communicating the messages of environmental friendliness and awareness to the societies. This can be done through practical creative activities such as drama, songs, debates, symposia, workshop etc on environmental conservation and protection.

\section{Recycling of wastes}

Solid wastes come from quarries, industrial processes, homes, businesses and educational institutions. Government, bussiness people, private organizations and individuals should pursue the process of wastes recycling to face the earth from serious pollution.

\section{Cleaning up the pollutions}

clean up campaigns on the highly polluted areas and water bodies should be stepped up. Grants to clean up projects and researches should be liberalized, it should be legally obligatory that any industries responsible for creating wastes should dispose of them, whether through incineration, burial landfill or any other method. 


\section{Ecology \& Conservation Science: Open Access}

\section{Environmental education and awareness creation}

These should be given priority attention, particularly in the educational curriculum to be able to monitor the environmental changes, sources of such changes and their impact on man, plant and animals, utilized sustainably the natural resources for the current development of humanity and the total development in future. Unfortunately, Nigerians are poorly aware of their environment and the damages being done to it through various activities like deforestation, bush burning, littering/open dumping of human waste, polluting rivers with sewage among others. Also, the changing climatic patterns and their increasingly grievous consequences are little appreciated. There is still inadequate established environmental protocol or information system for Government Executives, parents, teachers and the youth, to enable them access environmental information. However, the current provisions in national educational curricular, as well as research and development programmes are inadequate in providing environmental awareness. In addition, there is the challenges of weak environmental legislation and enforcement to coordinate environmental planning and action [55]. Given the worlds increasing technological sophistication and the close interaction between technological progress and environmental concerns, there is therefore needed to develop an environmentally literate citizenry. Both formal and informal environmental education would be effective an effective means to involve creating appropriate awareness of critical environmental issues. In particular, formal education is important to increase awareness, improve extension services, sensitize people on environmental issues and build institutional capacities. Nonformal environmental education tends to benefits people outside the formal education system. Communication of environmental information to all stakeholders is still a challenge. Public awareness empowers the public to develop a strong sense of responsibility on environmental issues [55].

\section{Empirical studies}

There is need for proper studies to be carried/directed at finding out the degree and kinds of toxic food, water supply, amount of radio activities contained in industrial wastes, the effect of water on soil degradation/pollution arising from the use of chemical fertilizers among others as a basis for further actions on environmental pollution.

\section{Conclusion}

The environment is a complex interwoven system. Its conservation, management and protection are an expensive business thus, requires that many hands are on deck together in a coordinated and strategic manner. Unfortunately, no one is interested in research, creativity, invention and innovation in environmental conservation. But without citizens buyin environmental protection and conservation, sustainable development would not happen. Citizens are the best defenders of their environments as they have the historical memories and knowledge about their environment and resources therein. The environment can be considered as part of the global commons as some of the cycles and mechanisms of nature operate across national boundaries. Actions in one nation often have direct impacts on another. The Earth Summit produced four major agreements which included the Rio Declaration on Environment and Development (citing the rights and responsibilities of individual states), the convention on climate changes, Agenda 21 (approaches for sustainable development) and the convention on Biological Diversity (CBD). These agreements have been the focus for conservation initiatives.

Remarkably, studies have shown that "One in four women worldwide or about 620 million women rate their lives positively enough to be considered 'thriving,", According to Gallup. "The life ratings of the rest or about 2 billion women place them in a category of 'struggling' or 'suffering'." The results reveal that women in developed countries tend to view themselves as thriving. Iceland, Sweden, and Denmark topped the list, with 77 to 68 percent of women in these countries saying they were thriving. These countries and others like them with more than 60 percent of their women thriving, including the United States, Australia, and Austria, also rank highly on the UN's Human Development Index. Gallup believes this correlation suggests that countries with strong economic and human rights offer a better environment for women. Unstable nations, on the other hand, such as Afghanistan, Ukraine, and Egypt, are home to the greatest number of suffering women. Physical conflict is not the only negative indicator, though, as Greece and Bulgaria also scored highly on the suffering list. Economic devastation appears to impact the lives of women just as deeply as military conflict, and the divide between thriving and suffering in many countries remains dismally wide, with most respondents falling into the struggling category [56].

With women suffering most in areas affected by conflict, it is evident that women's lives are closely linked to stability, development, and economic prosperity. Although the overall figures show that many women's lives around the world are difficult, the study also indicates that many rates the quality of their lives generally higher than men, suggesting they can play a critical role in improving their nations. "Encouraging women's participation particularly in emerging markets where gender gaps are widest not only can improve how women are doing, but also can fuel economic growth in their countries," Gallup concluded. The first step, perhaps, would be to transform their positive daily experiences into positive valued contributions to society. This, in turn, would help to promote their country's quality of life on the whole giving momentum to a virtuous cycle.

\section{Recommendations}

a) Mainstream women and equity in all sustainable development policies.

b) The protection of women decision- makers, planners, advisers and managers related to environmental management should be increased. 


\section{Ecology \& Conservation Science: Open Access}

c) Eliminate all harmful cultural, religious and social gender inequalities

d) Environmental education and awareness creation should be expanded in rural areas. Nigerians are poorly aware of their environment and the damages being done to it through various activities like bush burning, littering/open dumping of human waste, polluting rivers with sewage among others. There is a need to develop an environmentally literate citizenry. Formal and informal environmental education would be effective means to involve creating appropriate awareness of critical environmental issues. Formal education is important to increase awareness, improve extension services, sensitize people on environmental issues and build institutional capacities. Non-formal environmental education benefits people outside the formal education system. Communication of environmental information to all stakeholders is still a challenge. Public awareness empowers the public to develop a strong sense of responsibility on environmental issues.

e) Undertake a comprehensive curriculum reviews that integrate environment and development concepts in education curricular at primary, secondary and tertiary levels.

f) Document, disseminate and encourage the use of indigenous knowledge in environmental protection and conservation.

g) Implement full participation of women, girls and boys as agents of development

h) Provide incentives that attract underrepresented women and other vulnerable groups.

i) Support initiatives that ensure financial independence for women.

j) Women when once mobilized play a significant role in environmental protection.

k) The potential of Science and Technology should be utilized to solve environmental related problems and ease women's workload inside and outside the home and promote the development and utilization of clean technologies in national development. As relationships among science, technology, the environment and society are intricate and delicate. The use of sustainable technologies is critical for environmental sustainability.

l) The central government should develop a strategy to eliminate various obstacles constitutional, legal, administrative, social and economic in nature to women's full participation in sustainable development.

m) The Government, Non- Governmental Organizations, Environmental Conservation agencies and the common man should recognize and mobilize women as active participants to protect and enrich the natural resources that sustain us. n) Despite all these aspects there must be promotion of disseminating the gender relevant knowledge and valuations of women's role through formal and non-formal education.

\section{References}

1. Odoemena CSI, Egwali EC (2006) Fundamentals of conservation and development of Natural Resources in Nigeria. Unwana Graphics Press, Uyo, AKS.

2. Birnie $P$ and Boyle $A$ (2002) International Law and the Environment. ( $2^{\text {nd }}$ edn) $)$ Oxford, USA.

3. Olalekan RM, Omidiji AO, Williams EA, Christianah MB, Modupe O (2019) The roles of all tiers of government and development partners in environmental conservation of natural resource: a case study in $\mathrm{Ni}$ geria. MOJ Ecology \& Environmental Sciences 4(3): 114-121.

4. Enrique I (1995) Protection of forests and other Natural Resources: A View for Central America. In Social Aspects of Sustainable Dryland Management. John Wiley and Sons. UNEP, Nairobi.

5. Gill SE, Handley JF, Ennos AR, Pauleit S (2007) Adapting cities for climate change: the role of the green infrastructure. Built Environ 33(1): 115-133.

6. Nigerian Conservation Foundation (NCF) (2015) Nigeria: Fifth National Biodiversity Report.

7. Daniel S (1995) Social Aspects of Sustainable Dryland Management. John Wiley and Sons. UNEP, Nairobi.

8. Danielsson L, Jakobson H (2008) Three perspectives on women and the gender impasse in the Mozambican district of Nacala Porto (MSC Thesis). Vaxjo university, school of social science.

9. Parpart JL, Connelly MP, Barriteau VE (2000) Theoretical Perspectives on Gender and Development. IDRC.

10. Razavi S, Miller C (1995) From WID to GAD: Conceptual Shifts in the Women and Development Discourse. United Nations Research Institute for Social Development (UNRISD) Geneva Switzerland. United Nations Development Programme, pp. 55.

11. Tasli K (2007) A Conceptual Framework for Gender and Development Studies: From Welfare to Empowerment. ÖFSE Forum 32.

12. Parker B (2003) Planning Analysis: The Theory of Citizen Participation.

13. Claridge T (2004) Designing social capital sensitive participation methodologies. Report, Social Capital Research, Brisbane, Australia.

14. Quick KS, Bryson J (2016) Theories of public participation in governance.

15. Shiva V (1988) Staying Alive: Women, Ecology and Survival in India. New Delhi: Kali for India.

16. Baviskar A (1995) In the Belly of the River: Tribal Conflicts over Development in the Narmada Valley. Delhi: Oxford University Press 45(2): $255-261$.

17. Warren KJ (ed) (1994) Introduction. Ecological Feminism. London New York: Routledge, USA.

18. Akwa L, Marcus ND, Rahman SA (2008) Analysis of Fuel Wood Utilization Among Rural Women in Akwanga Area of Nasarawa State. Nigeria. The Abuja Journal of Geography and Development 1(2).

19. Raymond EW, Jane SPM, Thandiwe MD, Winnipeg, Manitoba (1994) The Needs of Women in Disaster and Emergencies. United Nations Development Programme.

20. Rao M (2012) Ecofeminism at the Crossroads in India: A Review. DEP 20(12): 124-142. 


\section{Ecology \& Conservation Science: Open Access}

21. Gottlieb RS (1996) This Sacred Earth: Religion, Nature, Environment. London: Routledge.

22. Moksha (2017) Bishnoi Communication for Perfect Life, Death and Enlightenment: An Ecological Perspective. Scientific Journal of International Research 1(2): 91-114

23. Bhatt CP (1992) Chipko andolan: Forest Conservation Based on People's Power. Environment and Urbanization 2(1): 7-18.

24. Jain S (1984) Women and People's Ecological Movement: A Case Study of Women's' Role in the Chipko Movement in Uttar Pradesh, Economic and Political Weekly 19(41): 1788-1794.

25. Ghanashyam B (2008) NREGA -Bringing Hope to Small Farmers.

26. Srinivasaraju S (2013) Once there was a River.

27. Mondal P (2015) Appiko Movement in India (Useful Notes).

28. Klassen C (2013) Indian villagers hug trees (Appiko) to stop deforestation in Karnataka, 1983-1990.

29. Ajayan (2009) Silent Valley: 25 years of an Ecological Triumph.

30. Dattatri S (2011) Silent Valley - A People's Movement That Saved a Forest.

31. Rohith P (2012) The Silent Valley and its discontents: literary environmentalism and the ecological discourse in Kerala (1975-1984). (Doctoral Thesis) University of Hyderabad, India.

32. Chengappa R (2009) 1976-Silent Valley movements: The genesis of green.

33. Roy A (1999) The Greater Common Good.

34. Nakhoda, Zein (2010) Narmada Bachao Andolan (NBA) Forces End of World Bank Funding of Sardar Sarovar Dam, India, 1985-1993.

35. Warren KJ (2000) Ecofeminist Philosophy: A Western Perspective on What it is and Why It Matters. Lanham Md: Rowman \& Littlefield.

36. Shiva V, Barker D, Lokhart C (2011) The GMO Emperor has no Clothe. A Global Citizens Report on the State of GMOs - False Promises, Failed Technologies. Synthesis Report Published by Navdanya International.

37. Aditya SK (2016) Role of Women in Environmental Conservation. International Journal of Political Science and Development 4(4): 140145

38. Solomon ZW, Vincent CD, Arin HB, Daloeng HM, Baminda AB (2014) Women Participation in Environmental Protection and Management: Lessons from Plateau State, Nigeria. American Journal of Environmental Protection 2(2): 32-36.

39. Glazebrook T (2011) Women and Climate Change: A case Study from North Eastern Ghana. Hypathia 26(4): 762-782.

40. Shettima AG (1996) Gender issues in monitoring the environment: The case of Rural Nigeria. A paper presented at the 39th Annual conference of the Nigerian geographical Association, 5th -8th May, at University of Maiduguri, Nigeria.

41. Adebayo AA, Anyanwu SO (2005) Women participation in Environmental protection and management: Lesson from Adamawa, Nigeria paraclete 2(2): 32-26.
42. Frausin V, Fraser JA, Narmah W, Lahai MK, Winnebah TR, et al. (2014) God made the Soil, but we made it Fertile: Gender, Knowledge, and Practice in the Formation and use of African Dark Earth in Liberia and Sierra Leone. Hum Ecol 42(5): 695-710.

43. Majing O, Moses M, Regina E (2017) Underscoring the role of Nigerian rural women in environmental protection: Lessons from Makarfi in Kaduna State, Nigeria. African Journal of Environmental Science and Technology 11(5): 213-218.

44. Michael F (1995) Gender participation in Environment and Development Projects in Drylands. In Social Aspects of Sustainable Dryland Management. John Wiley and Sons. UNEP, Nairobi.

45. Jude F (2018) Women are championing mangrove conservation in $\mathrm{Ni}$ geria.

46. Colls A, Ash N, Ikkala N (2009) Ecosystem-based adaptation: a natural response to climate change. Switzerland: International Union for Conservation of Nature.

47. Munang R, Thiaw I, Alverson K, Mumba M, Liu J, et al. (2013) Climate change and Ecosystem-based Adaptation: a new pragmatic approach to buffering climate change impacts. Curr Opin Environ Sustain 5(1): 67-71.

48. Daily Trust (2011) Thursday, June 23, p. 53.

49. Drewniak B, Snyder P, Steiner A, Twine T, Wuebbles D (2014) Simulated changes in biogenic VOC emissions and ozone formation from habitat expansion of Acer Rubrum (red maple). Environ Res 9(1).

50. Cheng JJ, Berry P (2013) Health co-benefits and risks of public health adaptation strategies to climate change: a review of current literature. Int J Public Health 58(2): 305-311.

51. Smith KR, Woodward A, Campell LD, Chadee D, Honda Y, et al. (2014) Human health, impacts adaptation and co-benefits. Climate change: impacts, adaptation, and vulnerability Working Group II contribution to the IPCC 5th Assessment Report. Cambridge, UK and New York, NY, Cambridge University Press, USA.

52. Stone B, Vargo J, Liu P, Dana H, Anthony D, et al. (2014) Avoided heat-related mortality through climate adaptation strategies in three US cities. PLoS One 9: e100852.

53. Kwagala B (1999) Katwogo and Kawala Low- income Urban settlements in Kampala, Uganda; Gender and the management of Urban Environmental Health on D. L. smith, women managing resources. Mazingira institute, Nairobi.

54. Chukwu MN (2014) A Study on Gender Involvement in Environmental Protection in Pedro Village, Lagos. Acad J Interdiscip Stud 3(7): 20-24.

55. Raimi MO, Oipe OE, Nimisingha DS, Abdulraheem AF, Okolosi PE, et al. (2019) Assessment of Environmental Sanitation, Food Safety Knowledge, Handling Practice among Food Handlers of Bukateria Complexes in Iju Town, Akure North of Ondo-State, Nigeria. Acta Scientific Nutritional Health 3(6): 186-200.

56. http://www.unesco.org/news/en/unesco/events/prizes-and-celebrations/international-days/international-womens-day-2014. 
This work is licensed under Creative Commons Attribution 4.0 License DOI: 10.19080/ECOA.2019.01.555558
Your next submission with Juniper Publishers will reach you the below assets

- Quality Editorial service

- Swift Peer Review

- Reprints availability

- E-prints Service

- Manuscript Podcast for convenient understanding

- Global attainment for your research

- Manuscript accessibility in different formats (Pdf, E-pub, Full Text, Audio)

- Unceasing customer service

Track the below URL for one-step submission https://juniperpublishers.com/online-submission.php 